\title{
Gamma Radiation Synthesis of Colloidal Silver Nanoparticles
}

\author{
EDUARD MARIUS LUNGULESCU1, GABRIELA SBARCEA ${ }^{1 *}$, RADU SETNESCU1,2, NICOLETA NICULA ${ }^{1}$, ROBERT DUCU1, \\ ANA MARIA LUPU (LUCHIAN) ${ }^{1}$, IOANA ION ${ }^{1}$, VIRGIL MARINESCU ${ }^{1}$ \\ ${ }^{1}$ National R\&D Institute for Electrical Engineering (ICPE-CA), 313 Splaiul Unirii, 030138, Bucharest, Romania \\ ${ }^{2}$ Valahia University of Targoviste, Faculty of Sciences and Arts, 2 Carol I Str., 130024, Targoviste, Romania
}

\begin{abstract}
Radiochemical synthesis of metallic nanoparticles is an eco-friendly method allowing the obtaining of controlled size, well dispersed and highly stable particles at very mild conditions. Colloidal silver nanoparticles

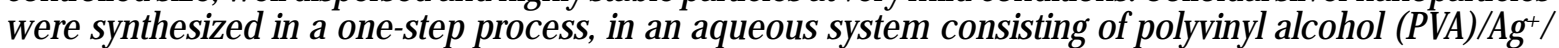
isopropyl alcohol (IPA), irradiated at various doses by using high energy ionizing radiations ( $\gamma$-rays). The UVVis spectra have shown a maximum absorption peak in the range of $390-450 \mathrm{~nm}$, specific for silver nanoparticles. The size of the obtained spherical shape nanoparticles was below $50 \mathrm{~nm}$ and decreased with increasing of the irradiation dose.
\end{abstract}

Keywords : metal nanoparticles, gamma irradiation, antimicrobial, silver nanoparticles

The current applications of ionizing radiation and their connection with nanotechnology representa research area that has gained special attention in recentyears [1-4]. The revolutionary development of science and engineering has enabled the synthesis of nano-sized materials in order to take advantage of their unique properties that differ significantly from those of the individual atoms $[5,6]$.

The nanoscale particles of transitional metals have unique physical and chemical properties that allow them to be used in a wide range of possible applications such as information storage, optoelectronics, sensors, renewable energy technologies and catalysts, medical imaging, biocidal or antimicrobial agents, etc. [7-15]. A number of factors such as size, dimensional distribution and particle shape have a major influence on the functional properties of these materials [16]. Consequently, there is an increased interest in the development of methods enabling better controlled synthesis of the nanoparticles [17]. Silver/ polymer based nanostructures are studied intensively due to their potential applications in electronics [18], optical devices [19], catalysis [20], biosensors [21], antibacterial medical devices [22] and in biomedical applications (wounds, tissue scaffolds, antimicrobial filters) towing to their antibacterial properties [23].

Silver nanoparticles are also used in the antimicrobial applications such as fungal, viruses and bacteria annihilation [24], obtaining of water filtration membranes with biocide activity against the microorganisms present in water [25] etc. The action of Ag nanoparticles on the biological systems depends on properties such as surface chemistry, size and shape, size distribution, morphology, particle composition and reactivity, agglomeration and dissolution rate, the efficiency of ions release and the type of reducing agents used for their synthesis [26]. The bioavailability of the therapeutic agents that are administered systemically and locally is enhanced by the physicochemical properties of the used nanoparticles [27]. The development of $\mathrm{Ag}$ nanoparticles with uniform structures in terms of size, morphology and functionality are essential for biomedical applications, because Ag nanoparticles can influence cellular absorption, biological distribution, penetration into biological barriers and the resulting therapeutic effects [28-30].

In this paper, colloidal solutions of silver nanoparticles were obtained by gamma ionizing radiation, starting from precursor systems containing silver ions (silver nitrate solution) stabilized with polyvinyl alcohol (PVA) in the presence of isopropyl alcohol. The effects of the irradiation dose on the ultimate characteristics of the radiationsynthesized silver nanoparticles, such as the average size, shape and antimicrobial properties, were studied.

\section{Experimenmtal part \\ Materials}

The materials used in the present work were silver nitrate as precursor (Chemical Company, Rumania), polyvinyl alcohol ( $M_{w}=89000-98000$, Sigma Aldrich) acting as a stabilizer of silver nanoparticles, isopropyl alcohol (IPA Chimreactiv SRL, Rumania) as radical $\mathrm{OH}^{\bullet}$ scavenger and deionized water as solvent. All reagents were used as received, without further purifications.

\section{Preparation of aqueous PVA/AgNO solution}

The solution of PVA $(6 \% \mathrm{~m} / \mathrm{v})$ was prepared under magnetic stirring at $98^{\circ} \mathrm{C}$ until a clear polymer solution was obtained. Then, an amount of $\mathrm{AgNO}_{3}$ corresponding to a concentration of $1 \mathrm{mM}$ was added into solution. The obtained solution was homogenized under magnetic stirring at $70^{\circ} \mathrm{C}$ for $1 \mathrm{~h}$, and the $\mathrm{pH}$ was kept constant at 89 by adding drops of $\mathrm{NaOH}$ solution. The solution was bubbled with $\mathrm{N}_{2}$ for $30 \mathrm{~min}$ for deaeration. Isopropyl alcohol was added to obtain a $20 \%$ v/v mixture with the PVA / Ag nitrate solution.

\section{Irradiation}

The PVA/Ag'/IPA solutions sealed in glass containers were exposed to $\gamma$-irradiation in an Ob-Servo Sanguis installation (Institute of Isotopes, Hungary), equipped with ${ }^{60} \mathrm{Co}$ source, at room temperature and atmospheric pressure. Radiation doses ranged from 0 to $100 \mathrm{kGy}$ at a dose rate of $1.2 \mathrm{kGy} / \mathrm{h}$.

\section{Characterization of silver nanoparticles}

UV-Vis Spectroscopy (J asco V-570, JP) was performed in the spectral range of $300-800 \mathrm{~nm}$, in PS vials of $1 \mathrm{~cm}$, with a resolution of $1 \mathrm{~nm}$, on colloidal solutions diluted with ultrapure water ( $4: 6 \mathrm{v} / \mathrm{v})$. Aqueous solution of PVA $(6 \%)$ was used as reference.

Infrared Spectroscopy (Jasco FTIR-4200, JP) was carried out in the spectral range of $400-4000 \mathrm{~cm}^{-1}$ with a resolution of $4 \mathrm{~cm}^{-1}$ and 50 scans /spectrum. For measurements, the colloidal nanoparticle solutions or the

\footnotetext{
* email: gabriela.sbarcea@icpe-ca.ro
} 
initial polymer solution were coated in a thin layer on a ZnSe window and the spectral acquisition was made in transmission mode.

The hydrodynamic diameter and particles size distribution were measured on diluted aqueous suspensions by Dynamic Light Scattering (DLS) technique using a 90 Plus nanoparticle size analyzer (Brookhaven Instruments Corporation) equipped with $35 \mathrm{~mW}$ solid-state laser with $660 \mathrm{~nm}$ wavelength. DLS measurements were performed at a scattering angle of $90^{\circ}$ and a temperature of $25^{\circ} \mathrm{C}$.

$X$-ray diffraction (XRD-Bruker-AXS type D8 DISCOVER) measurements were performed using the following parameters: X-ray tube with $\mathrm{Cu}$ anode, $40 \mathrm{kV} / 40 \mathrm{~mA}$; increment: 0.04 ; scanning rate: $1 \mathrm{~s}$; measuring range $2 \theta$ $=10^{\circ}-100^{\circ}$. The identification was performed using the database from International Center of Diffraction Data (ICDD).

All scanning electron microscopyimages were recorded with an FE-SEM model Auriga, Carl Zeiss, Germany involving in chamber secondary electron detector In-Lens annular type, with an accelerating voltage of $5 \mathrm{kV}$ on noncoated samples.

The antimicrobial tests were performed according to the following procedure: the exposure to a fungi suspension (a mixture of Aspergillus niger, Aspergillus terreus, Aureobasidium pullulans, Penicillium funiculosum, Penicillium ochrochloron, Paecilomyces variotii, Scopulariopsis brevicaulis, Trichoderma viride, Chaetomium globosum) was performed on complete Czapek-Dox culture media poured in Petri dishes, according to SR EN 60068-2-10 [31]. Fungal growth was observed at regular intervals of $3,7,14$ and 21 days;

The bacterial inoculum was represented by Staphylococcus sp. grown on LB agar (10 g peptone, $5 \mathrm{~g}$ yeast extract, $5 \mathrm{~g} \mathrm{NaCl}, 12 \mathrm{~g}$ agar), with a cellular density corresponding to 0.5 McFarland turbidity standard (150x106 $\mathrm{CFU} / \mathrm{mL}$ ). The volume of the colloidal silver nanoparticles solution used was $100 \mu \mathrm{L} /$ well.

\section{Results and discussions}

The radiochemical synthesis principle of metallic nanoparticles is based on the radiolysis of the aqueous solutions meaning transfers of a high amount of energy to the irradiated material, with several orders of magnitude higher than the average energy required to break any chemical bond; this energy transfer is non-selective.

The interaction of $\gamma$-radiation with aqueous solutions leads to the generation of free electrons by photoelectric absorption and Compton scattering, as well as to the production of primary species of water radiolysis such as hydrated electrons $\left(e_{a q}\right)$, hydrogen radicals, hydroxyl radicals, etc. [32].

$$
\mathrm{H}_{2} \mathrm{O} \stackrel{\gamma}{\longrightarrow} \mathrm{e}_{\text {aq }}^{-}, \mathrm{H}_{3} \mathrm{O}^{+}, \mathrm{H}^{*}, \mathrm{H}_{2}, \mathrm{OH}^{*}, \mathrm{H}_{2} \mathrm{O}_{2} \text { (1) }
$$

Hydrated electrons and hydrogen radicals ( $\mathrm{H}$ atoms) are strongly reducing species and can reduce $\mathrm{Ag}^{+}$ions to Ag metal (eq. (2)). The $\mathrm{Ag}^{0}$ atoms may interact with $\mathrm{Ag}^{+}$ ions by forming relatively stable clusters of silver (eq. (3)) [33]. Silver nanoparticles are formed either by combining these clusters or by absorbing a neutral $\mathrm{Ag}^{0}$ atom.

$$
\begin{aligned}
& \mathrm{Ag}^{+}+\mathrm{e}_{\mathrm{aq}}^{-} \stackrel{\text { reduction }}{\longrightarrow} \mathrm{Ag}^{0} \\
& \mathrm{Ag}^{0}+\mathrm{Ag}^{+} \rightarrow \mathrm{Ag}_{2}^{+} \\
& \mathrm{Ag}^{+}+\mathrm{Ag}_{2}^{+} \rightarrow \mathrm{Ag}_{3}^{+}
\end{aligned}
$$

On the other hand, hydroxyl radicals $\left(\mathrm{OH}^{\bullet}\right)$ resulting from the water radiolysis process have the ability to oxidize either ions or atoms to higher oxidation states. Therefore, in order to prevent this process, $\mathrm{OH} \times$ radical scavengers such as isopropyl alcohol are used [34].

\section{UV-Vis Spectroscopy}

A first indication of silver nanoparticle formation is given by color change of irradiated PVA $/ \mathrm{Ag}^{+}$/ IPA solutions: they gradually darken from transparent-colorless to yellow and then brown (fig. 1).
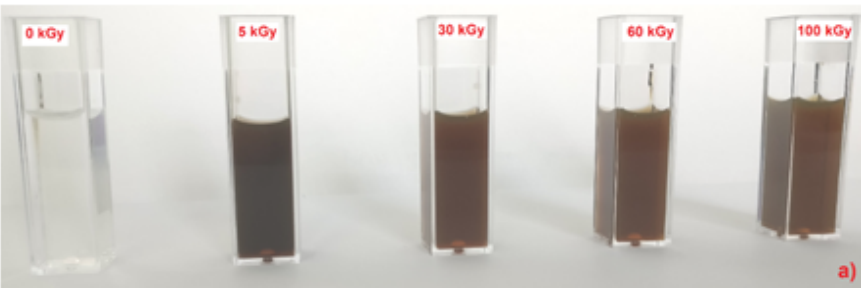

Fig.1.The color change of colloidal solutions with irradiation dose: $\mathrm{PVA} / \mathrm{Ag}^{+} / \mathrm{PA}$;

In order to confirm the formation of silver nanoparticles, UV-Vis absorption spectra of irradiated colloidal solutions were recorded. Figure 2 shows the UV-Vis spectra of colloidal silver nanoparticles. The optical absorption spectra of colloidal solutions of $\mathrm{Ag}$ nanoparticles is dominated by the SPR (Surface Plasmon Resonance) band [34]. Generally, silver nanoparticles show the specific SPR band with peaks between 390 and $500 \mathrm{~nm}$.

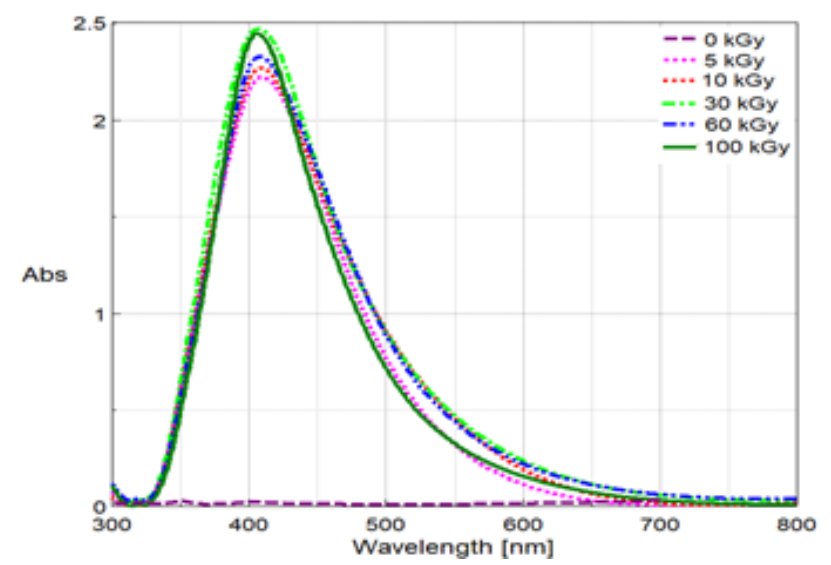

Fig.2. UV-Vis spectra recorded for PVA / Ag+ / IPA colloidal system. Solutions diluted with deionized water: 4:6 (v/v)

Table 1 summarizes the characteristic parameters of the SPR band for the analyzed samples. It can be seen that SPR maximum is slightly shifted to shorter wavelengths, and FWHM parameter decreases as the irradiation dose increased. The position and the shape of SPR band is dependent on both particles size and solution concentration $[34,35]$. SPR band moves to lower wavelengths with decreasing the average size of nanoparticles [36], and the height of this band increases as increasing the nanoparticles concentration. The FWHM parameter (full

Table 1

THE PARAMETERS OF SPR BAND

\begin{tabular}{|c|c|c|c|}
\hline $\begin{array}{c}\text { Dose } \\
\text { (kGy) }\end{array}$ & $\begin{array}{c}\text { Position of } \\
\text { maximum SPR } \\
\text { (nm) }\end{array}$ & $\begin{array}{c}\text { Absorbance* } \\
\text { (u.a.) }\end{array}$ & $\begin{array}{c}\text { FWHM } \\
\text { (nm) }\end{array}$ \\
\hline $\mathbf{5}$ & 410 & 2.20 & 112.3 \\
\hline 30 & 407 & 2.43 & 110.2 \\
\hline 60 & 408 & 2.29 & 112.4 \\
\hline 100 & 405 & 2.43 & 96.8 \\
\hline
\end{tabular}


width at half maximum) is correlated to the dispersion degree of nanoparticle dimensions: a high value of FW HM is associated with a large polydispersity [36]. Thus, it can be concluded that higher doses result in lower particle size and narrower dimensional distribution.

This behavior can be explained in terms of density of nucleation event: at high doses, the nucleation events are more present than the number of ions, radiation synthesis produces small nanoparticles and the process is followed by their aggregation. At low doses, when nucleation events are lower than the total number of ions, the metal nanoparticles have large dimensions [34].

On the other hand, a secondary reduction step induced by gamma radiation would be the intermolecular and intramolecular crosslinking processes between the polymer molecules, based on free radicals mechanism. Hence, at higher irradiation doses, the structure of the polymer matrix will be complex as a result of both formation of intermolecular and intramolecular hydrogen bonds, and radiation-crosslinking between the cyclic PVP molecules [37]. Thus, the coalescence of metallic nanoparticles is prevented, resulting the formation of smaller nanoparticles.

The stability tests carried-out on the silver nanoparticles colloidal solutions have evidenced their high stability even after a storage of 9 months in laboratory conditions; the visual examinations of the aqueous solutions did not present any deposits at the bottom of the glass containers and the SPR parameters obtained from UV-Vis spectra suffered slight modifications (fig. 3).
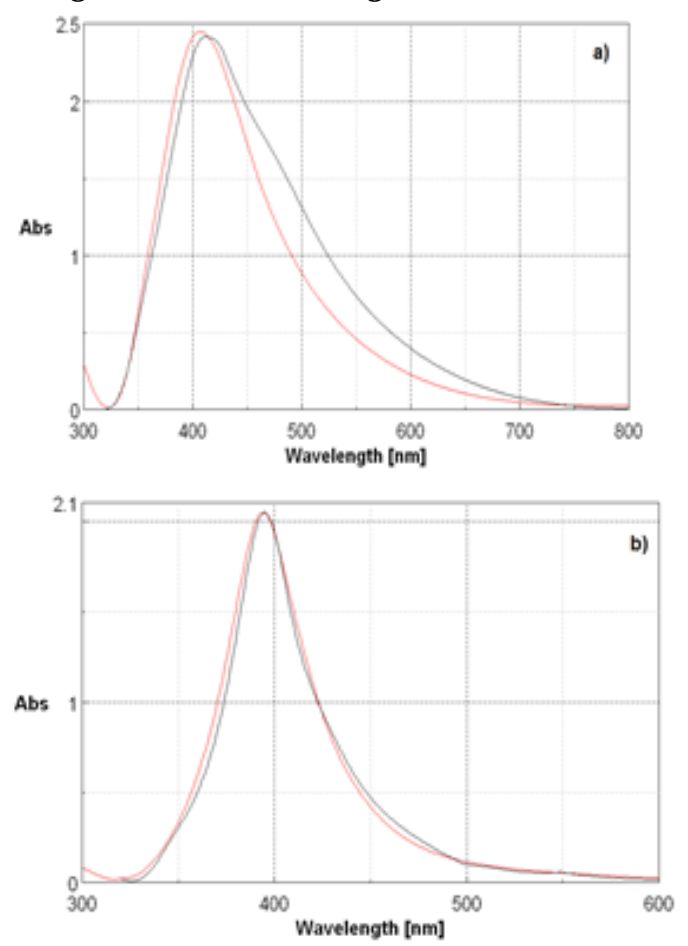

Fig.3. Influence of PVA concentration on the silver colloidal solutions stability ( $D=30 \mathrm{kGy}$ ): a) 80\% PVA: initial (red); after 9 months (black); b) 1 \% PVA: initial (red); after 9 months (black).

Solutions diluted with deionized water: 4:6 (v/v)
It has been observed that the concentration of the polymer has a great influence on the stability of the colloidal nanoparticle system. Thus, for the colloidal solutions with high PVA amount (about $80 \%$ ) and irradiated at $30 \mathrm{kG}$ it was observed a red shift of the SPR maximum of about $7 \mathrm{~nm}$, a slight decrease of 0.3 a.u. of the SPR intensity and a larger FW HM, respectively, as compared to the initial solutions (fig. 3a). At lower PVA concentration (bellow 20\%), the SPR parameters remain unmodified.

Taking into account this results we can conclude that radiation-synthesized silver nanoparticles present higher stability on long term.

\section{Dynamic light scattering (DLS)}

DLS measurements performed on the colloidal silver nanoparticles confirmed the results obtained by UV-Vis spectroscopy: the mean diameter $\left(D_{\text {mean }}\right)$ decreases with the irradiation dose from $30 \mathrm{~nm}$ to about $20 \mathrm{~nm}$.

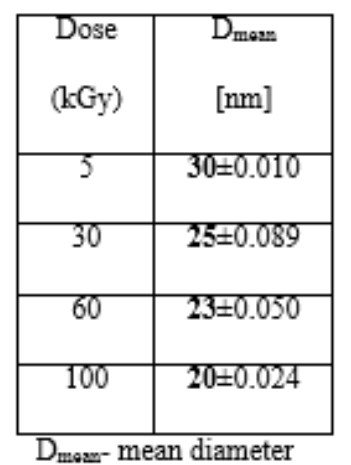

Table 2

THE VALUES OF MEAN DIAMETER DETERMINED BY DLS TECHNIQUE

\section{$X$-ray Diffraction}

The qualitative phase analysis by $X$-ray diffraction was used to determine the influence of the synthesis parameters on the crystalline structure of the radio-chemically synthesized Ag nanoparticles clusters. The analyzed samples present in XRD patterns four main peaks at $2 \theta=$ $38.4^{\circ}, 44,3^{\circ}, 64.8^{\circ}, 77.7^{\circ}$ and a very small peak at $81.8^{\circ}$ ( fig. 4). Their reflexions are indexed with the planes (111), (200), (220), (311), and (222), that correspond to the cubic face centered (FCC) crystallographic structure of silver. The crystallite size was calculated using Scherrer formula: $D=$ $\mathrm{K} \lambda / \beta \cdot \cos \theta$, where $\lambda$ is the wavelength of $X$-ray $(0.1541$ $\mathrm{nm}$ ), $\mathrm{K}$ is the shape factor (0.9), $\beta$ is FWHM (full width at half maximum), è represents the diffraction angle, and $D$ is the crystallite size. An increase in the intensity of the peaks can be observed with the irradiation dose (fig.3).

All the analyzed samples present a shift of the peaks to larger angles, resulting in lower cell parameters (table 3). A $0.4085 \mathrm{~nm}$ value was obtained according to the PDF card ICDD).

\section{Scanning Electronic Microscopy (SEM)}

This technique was used in order to analyze the morphological structure of the silver nanoparticles and for the determination of their size and shape. Figure 5 shows the SEM images obtained on colloidal systems, irradiated at $30 \mathrm{kGy}$. As can be seen, the radiation-synthesized silver

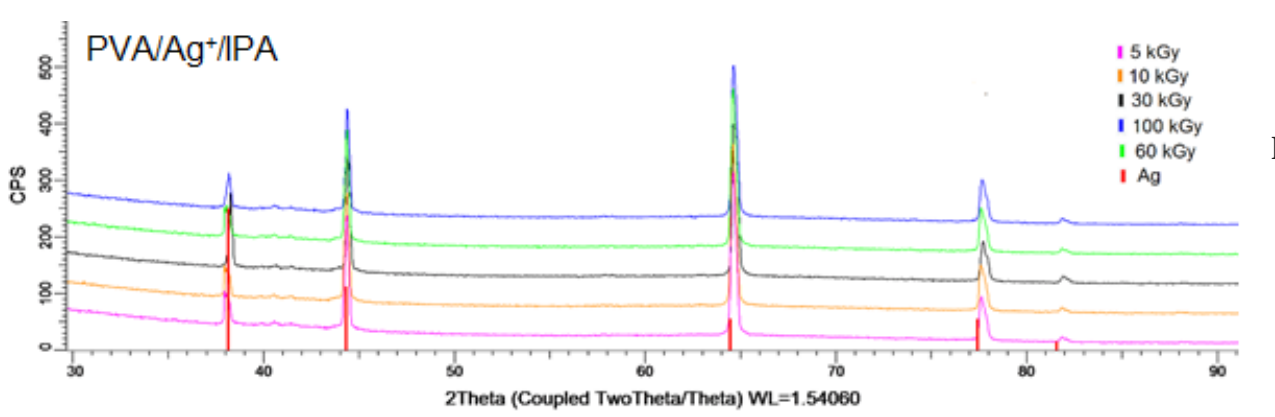

Fig. 4. XRD pattern obtained for PVA/Ag ${ }^{+} /$IPA colloidal system 
Table 3

CELL PARAMETERS OF PVA/AG+/IPA COLLOIDAL SYSTEM

\begin{tabular}{|c|c|c|c|c|}
\hline $\begin{array}{l}\text { Dose } \\
(k \mathrm{~Gy})\end{array}$ & $\begin{array}{c}\text { Crystallographic } \\
\text { phase }\end{array}$ & $2 \theta\left[^{\circ}\right]$ & $\begin{array}{l}\text { Lattice parameters } \\
\qquad a=b=c[n m]\end{array}$ & $\begin{array}{l}\text { Crystallite } \\
\text { size [nm] }\end{array}$ \\
\hline 5 & \multirow{5}{*}{ Cubic Ag } & \multirow{3}{*}{$\begin{array}{l}38.4 \\
44.3 \\
64.8\end{array}$} & 0.4077 & 31.6 \\
\hline 10 & & & 0.4077 & 31.6 \\
\hline 30 & & & 0.4071 & 30.9 \\
\hline 60 & & 77.7 & 0.4075 & 31.9 \\
\hline 100 & & 81.8 & 0.4072 & 31.1 \\
\hline
\end{tabular}

nanoparticles present mainly a spherical shape with the average dimensions similar to those obtained by DLS technique and in agreement with the SPR maximum peaks obtained from UV-Vis spectra.

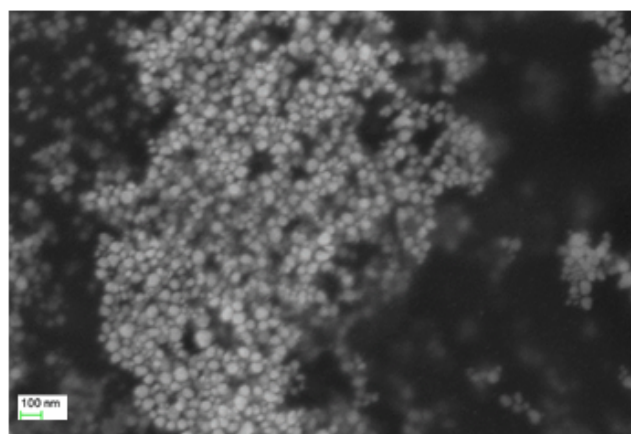

Fig. 5.SEM images recorded for PVA/Ag+/IPA colloidal system irradiated at $30 \mathrm{kGy}$

\section{Infrared Spectroscopy}

FTIR spectroscopy was used to prove the ability of PVA to coat and stabilize the silver nanoparticles. Figure 6shows the FTIR spectra recorded on the solutions of silver nanoparticles obtained in the presence of PVA, in comparison with the polymer solution without $\mathrm{Ag}$ nanoparticles. The formation of PVA-Ag bonds (due to the coating of Ag nanoparticles with PVA) produces changes in the PVA-Ag FTIR spectrum. Thus, it can be seen a decrease in the intensities of the bands corresponding to carbonyl or $-\mathrm{OH}$ active groups [38], i.e. $1745 \mathrm{~cm}^{-1}(\mathrm{C}=0)$, or $1424 \mathrm{~cm}^{-1}[(\mathrm{OH})-\mathrm{C}-\mathrm{OH}]$ and $1096 \mathrm{~cm}^{-1}[(\mathrm{CO})-\mathrm{C}-\mathrm{OH}]$, respectively, that suggests the formation of chemical bonds between PVA and Ag. PVA polymer chain plays an important role in avoiding the formation of Ag nanoparticles
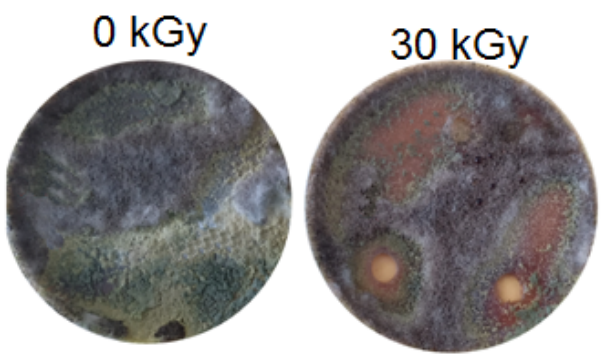

a)

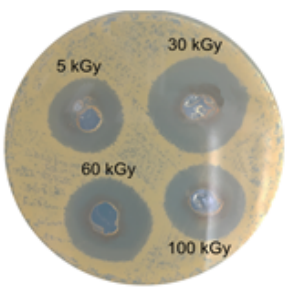

b)
Fig. 7. The efficiency of silver nanoparticles solutions: fungi suspension (a, $30 \mathrm{kGy}$ ); growth inhibition of Staphylococcus sp. (b)

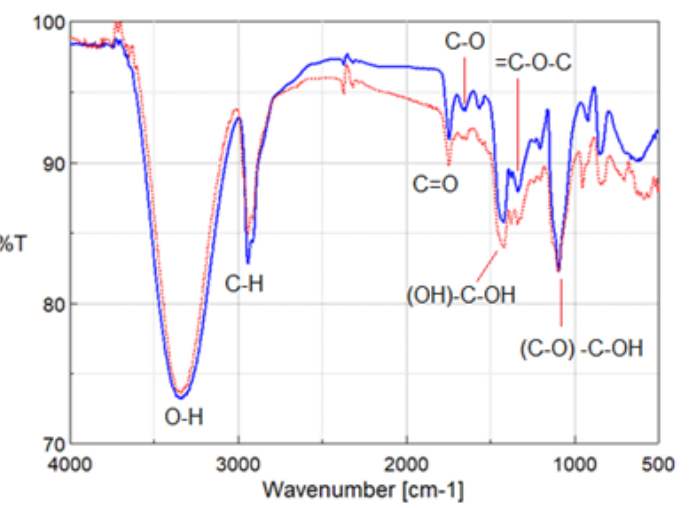

Fig. 6.Comparative FTIR spectra for PVA (without Ag, blue) and PVA/Ag+ (red) samples; Irradiation dose of $60 \mathrm{kGy}$

clusters. PVA contains several active $\mathrm{OH}$ groups which are able to retain $\mathrm{Ag}$ ions by secondary reactions and sterical hindrance [39], according to the following reaction:

$$
\mathrm{R}-\mathrm{OH}+\mathrm{Ag}^{+} \rightarrow \mathrm{R}-\mathrm{O}-\mathrm{Ag}+\mathrm{H}^{+}
$$

In this case, $\mathrm{R}-\mathrm{OH}$ represents the PVA monomer. Antimicrobial proprieties

These properties were illustrated in figure 7 . The exposure to both fungal and bacterial suspensions showed a local antimicrobial effect (fig. 7a). The sizes of the inhibition zones were between $20-26 \mathrm{~mm}$ (fig. $7 \mathrm{~b}$ ). The $100 \mathrm{kGy}$ irradiated samples showed zones of inhibition comparable in size with those of the $5 \mathrm{kGy}$ irradiated samples (approx. $21 \mathrm{~mm}$ ) even though the silver nanoparticles are smaller in size. This is due to the physical barrier created by the polymer which prevents the diffusion of the nanoparticles in the growth media. The barrier is created by structural modification of the polymer due to irradiation in which intramolecular crosslinking processes take place. This phenomenon becomes apparent starting with $60 \mathrm{kGy}$ and the polymer becomes visibly more viscous. The size of the inhibition zones created by the silver nanoparticles is comparable to the size of the inhibition zones created by commercial antibiotics [40], like oxacillin $(\geq 22 \mathrm{~mm}$ at $35 \mu \mathrm{g})$, gentamicin $(\geq 15 \mathrm{~mm}$ at $10 \mu \mathrm{g})$, kanamycin $(\geq 18 \mathrm{~mm}$ at $30 \mu \mathrm{g})$, tobramycin $(\geq 15 \mathrm{~mm}$ at

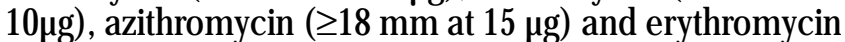
$(\geq 23 \mathrm{~mm}$ at $15 \mu \mathrm{g})$. The fungi suspension show ed a positive influence of the silver nanoparticles solutions. The solutions have an antifungal effect, with the maximum effect at 30 kGy. At higher doses, the efficiency is lower, probably due to the crosslinking of the polymer matrix.

Table 4

INHIBITION ZONES FOR STAPHYLOCOCCUS SP

\begin{tabular}{|c|c|}
\hline \multirow{2}{*}{$\begin{array}{c}\text { Dose } \\
\text { (kGy) }\end{array}$} & Inhibition zone (mm) \\
\cline { 2 - 2 } & PVA/Ag+/IPA \\
\hline 5 & 20 \\
\hline 30 & 26 \\
\hline 60 & 22 \\
\hline 100 & 21 \\
\hline
\end{tabular}




\section{Conclusions}

The experimental results have shown that the radiochemical synthesis is a simple and rapid method for obtaining controlled-size Ag nanoparticles, with good antimicrobial effectiveness.

The formation of radiation-induced Ag nanoparticles was visually confirmed by yellow-brown color of irradiated solutions, but also by the different analysis techniques, namely UV-Vis spectroscopy, XRD, DLS and SEM. The conclusions inferred from these measurements are perfectly convergent.

FTIR spectroscopy proved the coating ability of $\mathrm{Ag}$ nanoparticles by PVA component with the formation of chemical bonds between the polymer and silver nanoparticles. The polymer samples with Ag nanoparticles showed a decrease in the bands intensity of $\mathrm{C}=0$ groups $\left(1745 \mathrm{~cm}^{-1}\right)$ and of some active $-\mathrm{OH}$ bands compared to the initial polymer;

Radiation-synthesized Ag nanoparticles exhibit local antifungal and antibacterial activity (Staphylococcus sp.) with an inhibition zone of 21-26 mm. The antibacterial activity is similar to that of some commercial antibiotics (according to Clinical and Laboratory Standard Institute: penicillin, oxacillin, kanamycin, erythromycin, etc.). The antimicrobial activity is influenced by the average size of the nanoparticles, but it would be also affected by crosslinking of the polymer matrix which can prevent nanoparticle diffusion into the specific culture medium.

Acknowledgments:The financial support was provided by Ministry of Research and Innovation, through PN 19310101-46N/2019, Grant No 044-1122-2015/2020 and contract 30PFE/2018 (between National R\&D Institute for Electrical Engineering ICPE-CA and Romanian Ministry of Research and Innovation - $\mathrm{MCl}$ )

\section{References}

1. CHMIELEWSKI A.G., AL-SHEIKHLY M., BEREJ KAA.J., CLELAND M.R., ANTONIAK M. ,Radiat. Phys. Chem. 94, 2014, p.147-150

2. FARAHANI M., CLOCHARD M-C., GIFFORD I., BARKATT A., ALSHEIKHLY M. Radiat. Phys. Chem. 105, 2014, p. 39 - 47

3. PASANPHAN W., RATTANAWONGWIBOONT., CHOOFONG S., GÜVEN O., KATTI K.K., Radiat. Phys. Chem., 106, 2015, p. 360-370 4.POSTEK M.T., POSTER D.L., VLADAR A.E., DRISCOLL M.S., LAVERNE J.A., TSINAS Z., AL-SHEIKHLY M.I., Radiat. Phys. Chem. 143, 2018, p. 47-52

5. WANG L., ZHANG Z., HAN X., NPG Asia Mater., 5, 2013, p.40

6. MILLER J.C., SERRATO R.M., REPRESAS-CARDENAS J.M., KUNDAHL G.A. The Handbook of Nanotechnology. J ohn Wiley \& Sons, Inc., Hoboken, New Jersey, 2005

7. CAMPELO J .M., LUNA D., LUQUE R., MARINAS J .M., ROMERO A.A., ChemSusChem, 2, 2009, p.18-45

8. CUENYA B.R., Thin Solid Films, 518, 20103, p.127-3150

9. DATSYUK V., KALYVA M., PAPAGELIS K., PARTHENIOS, J., TASIS, D., SIOKOU, A., KALLITSIS, I., GALIOTIS, C., Carbon, 46, 2008, p.833-840 10. DU C., AO Q., CAO N., YANG L., LUO W., CHENG G., Int. J. Hydrog. Energy, 40, 2015, p.6180-6187

11. KAWASAKI, H., Nanotechnol. Rev., 2, 2013

12. KUILA T., BOSE S., MISHRA, A.K. KHANRA, P. KIM, N.H. LEE J.H., Prog. Mater. Sci., 57, 2012, p.1061-1105
13. MARQUARDT D., VOLLMER C., THOMANN R., STEURER P. MÜLHAUPT R. REDEL E. J ANIAK C., Carbon, 49, 2011, p.1326-1332

14. XU H., ZENG L., XING S., SHI G., XIAN Y., JIN L., Electrochem. Commun., 10, 2008, p.1839-1843

15. GHAZI O.A., IBRAHIM M.M., ABOU ELFADL F.I., HOSNI H.M., SHEHATA E.M., DEGHIEDY N.M., BALBOUL M.R., J. Radiat. Research. Appl. Sci., 8, 2015, p.166-172

16. GUISBIERS, G., ABUDUKELIMU, G., HOURLIER, D., Nanoscale Research Letters., 6, 2011, p.396

17. HEI, H., Soft Nanoscience Letters., 2, 2012, p.34-40

18. LI Y., WU Y., ONG B.S., J., Am. Chem. Soc., 127, 2005

p.3266-3267

19. MATSUDA S.I., YASUDA Y., ANDO S., Adv. Mater. 17, 2005, p.22212224

20. AHMED K.B.A., J. Photochem. Photobiol. B Biol., 151, 2015,

p. 39 - 45

21. LIU Y., WANG G., LI C., ZHOU Q., WANG M., YANG L., Mater. Sci. Eng., C 35, 2014, p.253 -258

22. SON W.K., YOUK J.H., LEE T.S., PARK W.H., Macromol. Rapid Commun. 25, 2004

p.1632-1637

23. FERRARIA A.M., BOU S., BATTAGLINI N., BOTELHO DO REGO A.M., REIVILAR M., Langmuir, 26, 2009, p.1996 -2001

24. MONTEIRO D.R., GORUP L.F., TAKAMIYA A.S., RUVOLLO-FILHO A.C., CAMARGO E.R.D., Int. J. Antimicrobial Agents, 34, 2009, p.103110

25. AHAMED M., ALSALHI M.S., SIDDIQUI M.K., Clin. Chim. Acta., 411, 2010, p.1841-1848

26.CARLSON, C.; HUSSAIN, S.M.; SCHRAND, A.M.; BRAYDICH-STOLLE, L.K.; HESS, K.L.; JONES, R.L.; SCHLAGER, J J., J. Phys. Chem. B, 112, 2008, p.13608-13619

27. JO, D.H.; KIM, J.H.; LEE, T.G.; KIM, J.H., Nanomedicine, 11, 2015, p.1603-1611

28. DUAN, X.P.; LI, Y.P., Small, 9, 2013, p.1521-1532

29. SRIRAM, M.I.; KANTH, S.B.M.; KALISHWARALAL, K.; GURUNATHAN, S. Int. J. Nanomed., 5, 2010, p.753-762

30. XI-FENG Z., ZHI-GUO L., WEI S., SANGILIYANDI G., Int. J. Medical Sciences, 2016

21.*** SR EN ISO 60068-2-10. Environmental testing -Part 2-10: Tests -

Test J and guidance : Mould growth, 2010

32. BELLONI J., Catal. Today, 2006, 113, p.141 -156

33. CHEN M., FENG Y.G., WANG X., LI T.C., ZHANG J.Y., Langmuir, 23, 2007, p.5296-5304

34. NAGHAVI K., SAION E., REZAEE K., YUNUS W.M.M., Radiat. Phys. Chem., 79, 2010, p.1203-1208

35. EGHBALIFAM N., FROUNCHI M., DADBIN., Int. J. Biol. Macromol., 80, 2015, p.170-178

36 AGNIHOTRI S., MUKHERJI S., MUKHERJI S., RSC Adv., 4, 2014, p.3974-3983

37. KASSAEE M., A. AKHAVAN, N. SHEIKH, R. BETESHOBABRUD., Radiat. Phys. Chem., 77, 2008, p.1074-1078

38. ABEDINI A, DAUD A.R., HAMID M.A.A., OTHMAN N. K., SAION E., Nanoscale Research Letters, 8, 2013, p.474-484

39. GAUTAM A., TRIPATHY P., RAM S., J. Mater. Sci., 41, 2006, p.30073016

40. ***Clinical and Laboratory Standard Institute: M100-S24 Performance standards for antimicrobial susceptibility Testing; Twenty-fourth informational supplement, 2014

Manuscript received: 3.12 .2018 